(c) American Dairy Science Association, 2005.

\title{
Assessment of the Impact of Somatic Cell Count on Functional Longevity in Holstein and Jersey Cattle Using Survival Analysis Methodology
}

\author{
D. Z. Caraviello, K. A. Weigel, G. E. Shook, and P. L. Ruegg \\ Department of Dairy Science, University of Wisconsin, Madison 53706
}

\begin{abstract}
Survival analysis in a Weibull proportional hazards model was used to evaluate the impact of somatic cell count (SCC) on the involuntary culling rate of US Holstein and Jersey cows with first calvings from 1990 to 2000. The full data set, consisting of records from 978,043 Holstein and 250,835 Jersey cows, was divided into subsets ( 5 for Holsteins and 3 for Jerseys) based on herd average lactation SCC values. Functional longevity (also known as herd life or length of productive life) was defined as days from first calving until culling or censoring, after correcting for milk production. Our model included the time-dependent effects of herd-yearseason, parity by stage of lactation interaction, withinherd-year quintile ranking for mature equivalent production, and lactation average SCC (rounded to the nearest 50,000 cells $/ \mathrm{mL}$ ), as well as the time-independent effect of age at first calving. Parameters of the Weibull distribution, as well as variance components for herd-year-season effects, were estimated within each group of herds. Mean failure and censoring times decreased as herd average SCC increased, and a nonlinear relationship was observed between SCC and longevity in all groups. The risk of culling for Holstein cows with lactation average $\mathrm{SCC}>700,000$ cells $/ \mathrm{mL}$ was 3.4 , 2.7 , or 2.3 times greater, respectively, than that of Holstein cows with SCC of 200,000 to 250,000 cells $/ \mathrm{mL}$ in herds with low, medium, or high average SCC. Likewise, the risk of culling for Jersey cows with lactation average SCC $>700,000$ cell $/ \mathrm{mL}$ was $4.0,2.9$, or 2.2 times greater, respectively, than that of Jersey cows with SCC of 200,000 to 250,000 cells $/ \mathrm{mL}$ in low, medium, or high SCC herds. These trends may reflect more stringent culling of high SCC cows in herds with few mastitis problems. In addition, cows with lactation average SCC $<100,000$ cells/mL had a slightly higher risk of culling than cows with SCC of 100,000 to 200,000 cells/mL in both breeds, particularly in herds with high
\end{abstract}

Received December 8, 2003.

Accepted August 29, 2004

Corresponding author: Kent Weigel; e-mail: kweigel@wisc.edu. average SCC, where exposure to mastitis pathogens was likely.

(Key words: longevity, somatic cell count, mastitis, survival analysis)

Abbreviation key: $\mathbf{C M}=$ clinical mastitis, $\mathbf{P L}=$ length of productive life, $\mathbf{R R}=$ relative risk of culling.

\section{INTRODUCTION}

Mastitis is the most frequent and costly disease in dairy cattle, and economic losses can be attributed to both clinical and subclinical disease. A cow's immune system responds to a bacterial invasion by sending white blood cells to the inflamed quarter, and SCC is a measure of the concentration of white blood cells and shed epithelial cells present in milk. In an uninfected udder, the SCC is generally $<200,000$ cells $/ \mathrm{mL}$, and higher concentrations often reflect bacterial infections (http://www.uwex.edu/milkquality/PDF/milksecretio nandqualitystandards.pdf). Subclinical mastitis occurs when a pathogen infects one or more quarters but does not cause enough disruption of the secretory alveoli to result in visibly abnormal milk. High SCC milk is undesirable for processors because it reduces the shelf life of dairy products and diminishes the quality and quantity of milk protein, thereby reducing cheese yields. Even modest increases in individual cow SCC (e.g., $>100,000$ cells $/ \mathrm{mL}$ ) have been shown to reduce cheese yield (Barbano et al., 1991).

Individual cow SCC values are routinely used as a tool for involuntary culling decisions on commercial dairies, and PTA of dairy sires for SCS are commonly used for genetic selection decisions and routinely incorporated into economic indices, such as Lifetime Net Merit. Estimates of the genetic correlation between SCC and clinical mastitis (CM) are generally large and positive. For example, Rupp and Boichard (1999) reported an estimated correlation of 0.72 in French Holsteins. In Israeli Holsteins, Weller et al. (1992) reported an estimated genetic correlation of 0.994 between SCC and the incidence of bacterial subclinical infection; however, the estimated correlation between SCC and producer-recorded CM was only 0.299. Cranford and Pear- 
son (2001) noted that a strong relationship exists between sires' PTA for SCS and the incidence rate of CM in their daughters. Furthermore, SCC is routinely recorded on all cows in an objective manner, using a continuous scale of measurement. On the contrary, CM is scored in a binary manner, and both the diagnosis and (decision to apply) treatment are subjective. For these reasons, heritability estimates for SCC are generally greater in magnitude than corresponding estimates for CM. For example, heritability estimates reported by Rupp and Boichard (1999) were 0.17 for SCC and 0.02 for CM.

The longevity or survival rate of dairy cows can be influenced by SCC through the death or culling of clinically affected animals, as well as the culling of subclinical animals with high SCC (to achieve milk quality premiums). Cranford and Pearson (2001) found significant, unfavorable correlations between sire PTA for SCS and the number of lactations, total (lifetime) DIM, and length of productive life (PL) of their daughters. The magnitude of these relationships increased considerably when sire PTA for SCS were adjusted to a constant level of PTA for milk yield. For example, a onepoint increase in sire PTA for SCS corresponded to a decrease of $87 \mathrm{~d}$ in PL before standardization to a constant level of milk yield, and $132 \mathrm{~d}$ after this standardization.

A potential complication in statistical analyses is that SCC is a time-dependent variable. The SCC of an individual cow changes over time, as does the likelihood that its current SCC level will lead to removal from the herd. Survival analysis methodology effectively uses information from time-dependent covariates and is capable of handling censored observations, so data from animals that are still alive at the time of analysis can be used (Ducrocq and Sölkner, 1998a; Vukasinovic, 1999). Furthermore, the distribution of longevity data is often skewed, and methods based on the assumption of normality have limited applicability to the analysis of longevity data (Egger-Danner, 1993).

Gröhn et al. (1998) used a Cox proportional hazards model, with time-dependent covariates, to assess the impact of CM and other diseases on culling rates in New York State. The number of days from first calving until culling or censoring was reduced significantly by a CM infection, regardless of whether the infection occurred in early, middle, or late lactation. However, the influence of $\mathrm{CM}$ on the risk of culling was influenced only minimally by the inclusion of milk yield as a covariate.

Likewise, Neerhof et al. (2000) used survival analysis methodology to investigate the impact of mastitis on functional longevity in Danish Black and White cattle. These authors noted the importance of considering the long-term impact of $\mathrm{CM}$ on culling decisions; models in which a CM episode was assumed to influence longevity until the end of the lactation provided the best fit to the data. After adjusting for parity, stage of lactation, previous lactation milk yield, age at first calving, and proportion of Holstein genes, the relative risk of culling for a cow with CM was 1.69 times that of an uninfected cow. Among bulls with at least 100 uncensored daughters, the product-moment correlation between sires' genetic evaluations for $\mathrm{CM}$ and the relative risk of culling (RR) of their daughters was -0.40 .

The objective of this study was to use individual cow SCC data to estimate the impact of clinical and subclinical mastitis on the functional longevity of US Holstein and Jersey cows using survival analysis methodology.

\section{MATERIALS AND METHODS}

The USDA Animal Improvement Programs Laboratory provided data, which included survival, milk production, and SCC records of 250,835 Jersey cows and 978,043 Holstein cows with first calving from 1990 to 2000. All animals were required to have valid sire identification, as well as age at first calving between 18 and 42 mo of age. Herds were assigned to categories based on the mean of lactation average SCC for all eligible cows in each herd over the 10-yr period. Jersey herds were divided into 3 categories, corresponding to low $(139,000$ to 306,000 cells $/ \mathrm{mL})$, medium $(306,000$ to 349,000 cells $/ \mathrm{mL}$ ), or high ( 349,000 to 491,000 cells $/ \mathrm{mL}$ ) lactation average SCC. Holstein herds were divided into 5 categories, consisting of herds with low $(111,000$ to $279,000$ cell $/ \mathrm{mL})$, medium-low $(279,000$ to 305,000 cells $/ \mathrm{mL})$, medium $(305,000$ to 329,000 cells $/ \mathrm{mL})$, medium-high $(329,000$ to 358,000 cells $/ \mathrm{mL})$, or high (358,000 to 540,000 cells $/ \mathrm{mL}$ ) lactation average SCC.

Longevity, also commonly known as herd life or PL, was defined as the number of days from first calving until culling or censoring. Records from cows that were sold for dairy purposes were considered as censored, as were records from cows that resided in herds that discontinued milk recording, cows that were still alive after 5 completed lactations, and cows that were still alive when the data were extracted. Cows that completed a 305-d lactation but did not calve again within 6 mo were considered dead and were treated as uncensored. Functional longevity is the ability to delay involuntary culling, because voluntary culling for low production can be an important reason for disposal. Functional longevity can be approximated by correcting true longevity for production level (Ducrocq and Sölkner, 1998a). Therefore, we created quintiles for within herdyear 305-d mature equivalent milk yield (in Jerseys) or 305-d mature equivalent fat plus protein yield (in 


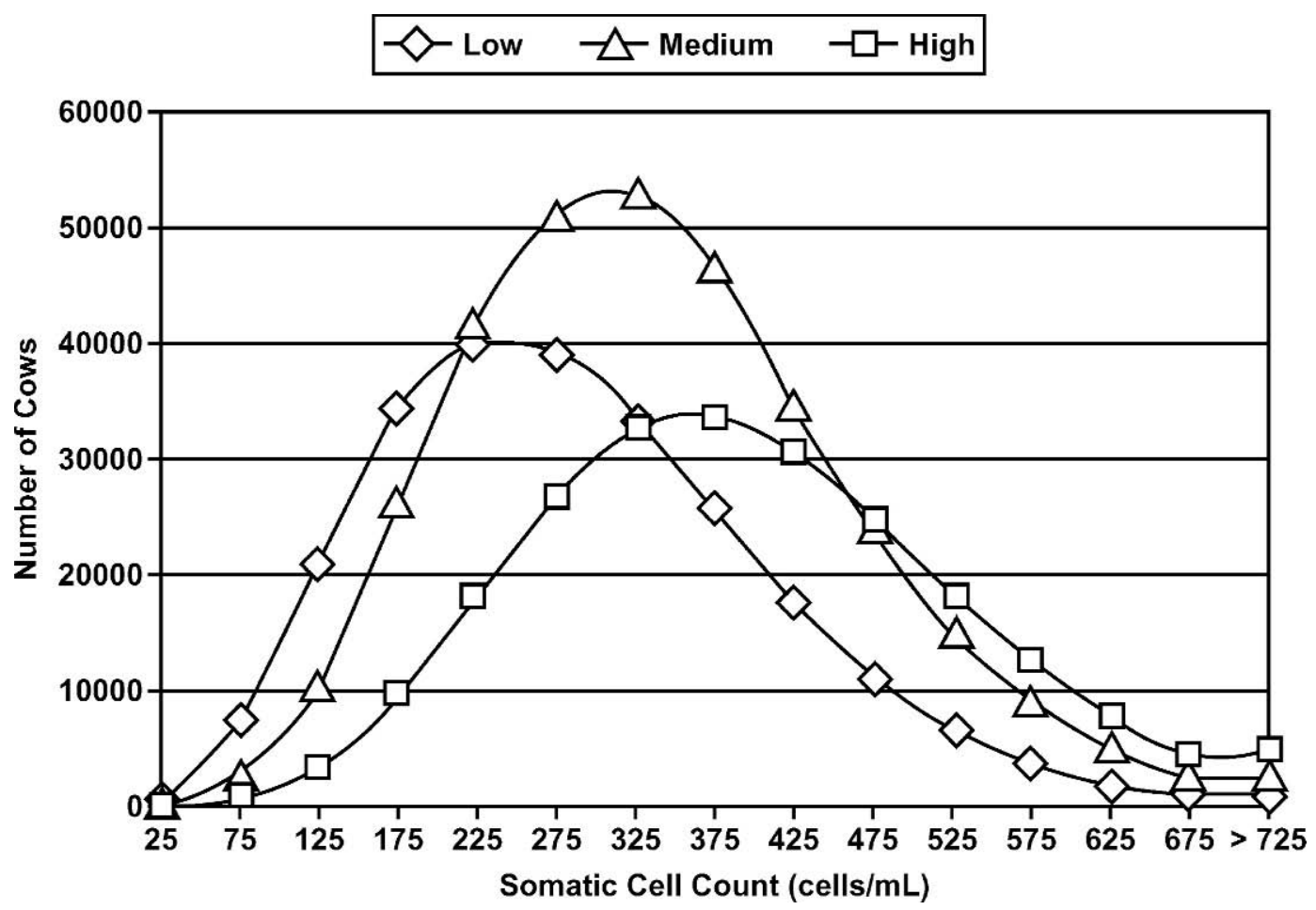

Figure 1. Distribution of lactation average SCC values for Jersey cows in low, medium, and high average SCC herds.

Holsteins, for which low component percentages are more likely to be a problem).

The statistical model for analyzing the impact of SCC on functional longevity was as follows:

$$
\begin{aligned}
h_{i j k l m}(t) & =h_{\mathrm{o}}(t) \exp \left[P_{i}\left(t_{1}\right)+\beta A_{j}+M_{k}\left(t_{2}\right)\right. \\
& \left.+h_{y s_{l}}\left(t_{2}\right)+S C C_{m}\left(t_{2}\right)\right]
\end{aligned}
$$

where $h_{i j k l m}(t)=$ hazard function (instantaneous probability of culling) for a given cow at $t$ days since first calving; $h_{0}(t)=$ Weibull baseline hazard function with scale parameter $\tau$ and shape parameter $\rho ; P_{i}\left(t_{1}\right)=$ timedependent fixed parity-stage of lactation effect, assumed to be piecewise constant with change points at $t_{1}=0,45$, and $270 \mathrm{~d}$ postpartum in lactations $1,2,3$, 4 , and $5 ; A_{j}=$ time-independent effect of age at first calving, treated as a continuous covariate with regression coefficient $\beta ; M_{k}\left(t_{2}\right)=$ time-dependent effect of within-herd-year quintile ranking for mature equivalent $305 \mathrm{~d}$ milk yield (Jerseys) or combined fat and protein yield (Holsteins), assumed to be piecewise constant with change points at $t_{2}=$ calendar dates of calving in lactations $1,2,3,4$, and 5 ; $h y s_{l}\left(t_{2}\right)=$ time-dependent random effect of herd-year-season, assumed to be independently distributed, following a log-gamma distribution with parameter $\gamma$, and assumed to be piecewise constant with change points at $t_{2}=$ January
1, May 1, and September 1 of each calendar year; $S C C_{m}\left(t_{2}\right)=$ time-dependent effect of lactation average SCC, grouped into 15 classes (to nearest 50,000 cells/ $\mathrm{mL}$ ) and assumed to be piecewise constant with changes at $t_{2}=$ calendar dates of calving in lactations $1,2,3,4$, and 5 .

This model was applied to data from each category of herds independently, such that separate estimates were obtained for $\rho$ (the shape parameter of the Weibull distribution) and $\gamma$ (the parameter of the log-gamma distribution of herd-year-season effects). In addition to overall culling, the DHI culling codes corresponding to individual cows were used to identify cows that (according to the herd owner) were culled due to mastitis. We subsequently repeated each analysis, but in this case longevity records were considered completed only if cows were culled due to mastitis; longevity records from cows that were culled for any other reason were considered censored. In this manner, it was possible to determine the impact of SCC on cows' overall risk of culling, as well as the impact of SCC on cows' risk of culling for mastitis. One must recognize, however, that assignment of reasons for culling by dairy farmers is often imprecise. For example, a nonpregnant cow with poor milk production may be culled after a CM episode, but the farmer could report the corresponding reason for culling as mastitis, low production, or infertility. 


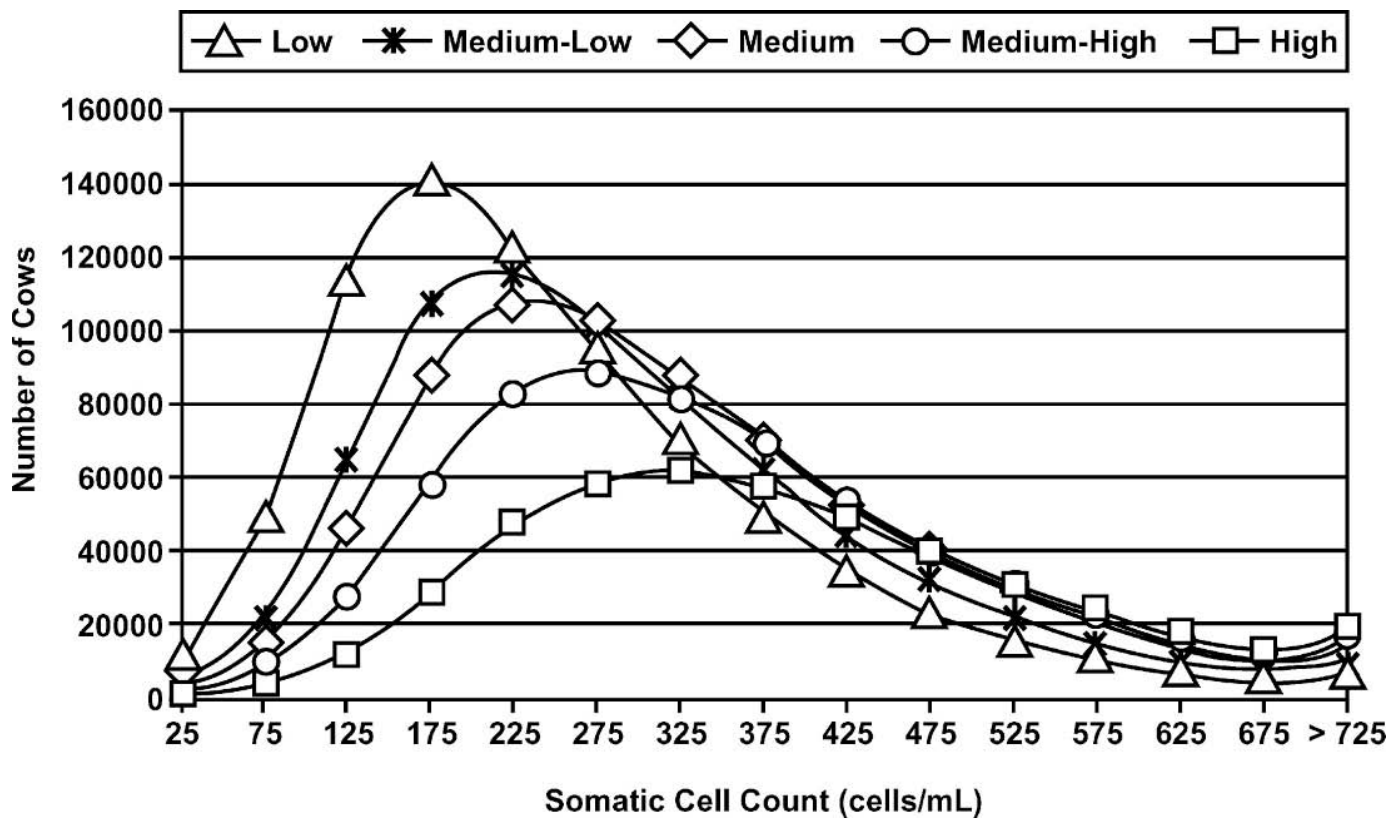

Figure 2. Distribution of lactation average SCC values for Holstein cows in low, medium-low, medium, medium-high, and high average SCC herds.

The present study used lactation average SCC data for each cow, rather than individual test-day SCC records, primarily due to computational limitations, concern about month-to-month variation in test-day SCC measurements (e.g., if the DHI tester happens to arrive on the day a particular cow has CM), and lack of monthly SCC data for herds enrolled in labor-efficient milk recording programs (e.g., herds with bimonthly or quarterly SCC options). However, it is likely that test-day SCC data would have provided more precise information about the udder health status of individual cows at specific times. The Survival Kit Version 3.12, a set of FORTRAN programs by Ducrocq and Sölkner (1998b), was used for the analysis. Cows with lactation average SCC of 200,000 to 250,000 cells $/ \mathrm{mL}$ were considered "average", and their RR estimates were constrained to unity.

\section{RESULTS AND DISCUSSION}

The frequency distribution of lactation average SCC of individual Jersey cows in herds with low $(139,000$ to 306,000 cells $/ \mathrm{mL}$ ), medium (306,000 to 349,000 cells/ $\mathrm{mL})$, or high $(349,000$ to 491,000 cells $/ \mathrm{mL})$ average $\mathrm{SCC}$ is shown in Figure 1, and the corresponding frequency distribution of lactation average SCC of individual Holstein cows in low $(111,000$ to 279,000 cells $/ \mathrm{mL})$, medium-low $(279,000$ to 305,000 cells $/ \mathrm{mL})$, medium (305,000 to 329,000 cells $/ \mathrm{mL})$, medium-high $(329,000$ to 358,000 cells $/ \mathrm{mL}$ ), or high ( 358,000 to 540,000 cells/
$\mathrm{mL}$ ) SCC herds is shown in Figure 2. As shown in these graphs, the frequency distributions of individual cow SCC values overlapped significantly between the various categories of herds.

A summary of the data, including mean failure time, percentage censoring, and mean censoring time for each breed and each SCC category, is provided in Table 1. These data suggest that Holstein and Jersey cows in herds with high average SCC tend to be culled earlier in life than cows that reside in herds with fewer udder health problems. The percentage of censored records was greater in low SCC herds (53\% in Jerseys and $43 \%$ in Holsteins), compared with herds with higher average SCC. This seems to indicate that a greater proportion of animals in these herds survived through 5 lactations, or at least until data were extracted for this study. Furthermore, the mean failure time for cows in low SCC herds (705 d for Jerseys and $661 \mathrm{~d}$ for Holsteins) was greater than the mean failure time in high SCC herds (680 d for Jerseys and $615 \mathrm{~d}$ for Holsteins). A similar trend was observed for the mean censoring time in low SCC herds $(789 \mathrm{~d}$ for Jerseys and $721 \mathrm{~d}$ for Holsteins) compared with high SCC herds (781 d for Jerseys and $684 \mathrm{~d}$ for Holsteins). Compared with Holsteins, Jerseys tended to have a higher percentage of censoring and higher mean failure and censoring times. These differences imply that Jersey cows are superior to Holstein cows in longevity. However, one must exercise caution when comparing the phenotypic longevity of different breeds, because animals of different breeds 
Table 1. Summary of the data, including number of cows, mean failure time, percentage of (right-)censored records, and mean censoring time for all culling (regardless of reason) and culling due to mastitis only, according to breed and herd average somatic cell count (SCC).

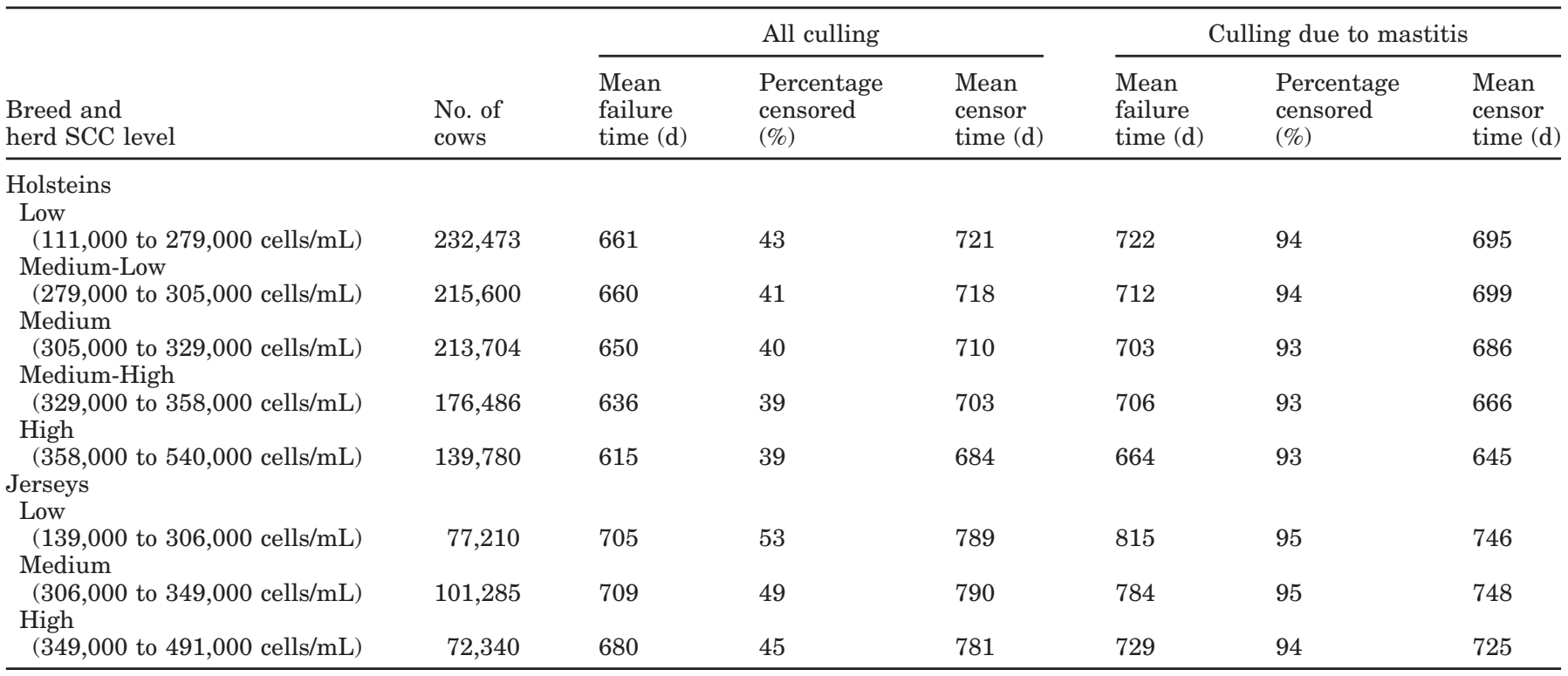

generally reside in different herds (i.e., data from mixed herds are limited), and these differences could reflect factors that are unrelated to health or fertility (e.g., breed popularity in the presence of multiple-component pricing of milk).

Mean failure time, percentage censoring, and mean censoring time when "failure" was constrained to reflect culling due to mastitis only are also provided in Table 1. Once again, low SCC herds had a higher mean failure time (815 $\mathrm{d}$ for Jerseys and $722 \mathrm{~d}$ for Holsteins) than high SCC herds (729 d for Jerseys and $664 \mathrm{~d}$ for Jerseys). Mean censoring time was also greater in low SCC herds (746 d for Jerseys and $695 \mathrm{~d}$ for Holsteins) than in high SCC herds (725 d for Jerseys and $645 \mathrm{~d}$ for Holsteins). These differences may reflect later (in life) exposure to pathogens and first incidence of $\mathrm{CM}$ among cows in low SCC herds, or they may be the result of superior protocol for detection and treatment of infected animals in low SCC herds.

The relative risk of overall culling or culling due to mastitis for Holstein cows with varying lactation average SCC in low (111,000 to 279,000 cells $/ \mathrm{mL}$ ), mediumlow $(279,000$ to 305,000 cells $/ \mathrm{mL})$, medium $(305,000$ to $329,000$ cells $/ \mathrm{mL})$, medium-high $(329,000$ to 358,000 cells $/ \mathrm{mL})$, or high $(358,000$ to 540,000 cells $/ \mathrm{mL})$ SCC Holstein herds is shown in Table 2. The relative risk of culling for individual Holstein cows with high SCC, relative to "average" Holstein cows with lactation SCC values of 200,000 to 250,000 cells $/ \mathrm{mL}$ and risk ratios of 1.0, was higher in herds with (otherwise) low average SCC. For example, Holstein cows with lactation average SCC $>700,000$ cells $/ \mathrm{mL}$ were roughly 4.4 times more likely to be culled than average cows in herds with low SCC. On the other hand, Holstein cows with lactation average SCC $>700,000$ cells $/ \mathrm{mL}$ were only 2.7 times more likely to be culled than average cows in herds with high SCC. Likewise, the relative risk of culling for Holstein cows with lactation average SCC of 600,000 to 650,000 cell $\mathrm{s} / \mathrm{mL}$ ranged from 2.0 in herds with low average SCC to approximately 1.6 in herds with high average SCC. Interestingly, Holstein cows with extremely low lactation average $\mathrm{SCC}(<50,000$ cells $/ \mathrm{mL})$ had a greater relative risk of culling than average cows, particularly in herds with medium-high or high SCC.

When failure was defined as culling due to mastitis only, Holstein cows with high lactation average SCC $>700,000$ cells $/ \mathrm{mL}$ were 26.3 times more likely to be culled (for mastitis) in herds with low SCC, as compared with cows in the 200,000 to 250,000 cells/mL category. In high SCC herds, Holstein cows with lactation average $\mathrm{SCC}>700,000$ cells $/ \mathrm{mL}$ were 19.4 times more likely to be culled for mastitis than cows in the intermediate class $(200,000$ to 250,000 cells $/ \mathrm{mL})$. Holstein cows with lactation average SCC of 600,000 to 650,000 cells $/ \mathrm{mL}$ were 8.1 times more likely to be culled for mastitis in herds with low SCC and 7.4 times more likely in herds with high SCC compared with average cows. These results suggest that one of the reasons for low herd average SCC is stricter culling of animals with CM or high SCC. Once again, Holstein cows with extremely low lactation average SCC had higher risk of culling due to mastitis than average cows, particularly in high SCC herds. 
Table 2. Relative risk of overall culling and culling due to mastitis for Holstein cows with differing lactation average SCC in low (111,000 to 279,000 cells $/ \mathrm{mL}$ ), medium-low ( 279,000 to 305,000 cells $/ \mathrm{mL}$ ), medium $(305,000$ to 329,000 cells $/ \mathrm{mL})$, medium-high ( 329,000 to 358,000 cells $/ \mathrm{mL})$, or high $(358,000$ to 540,000 cells $/ \mathrm{mL})$ SCC herds.

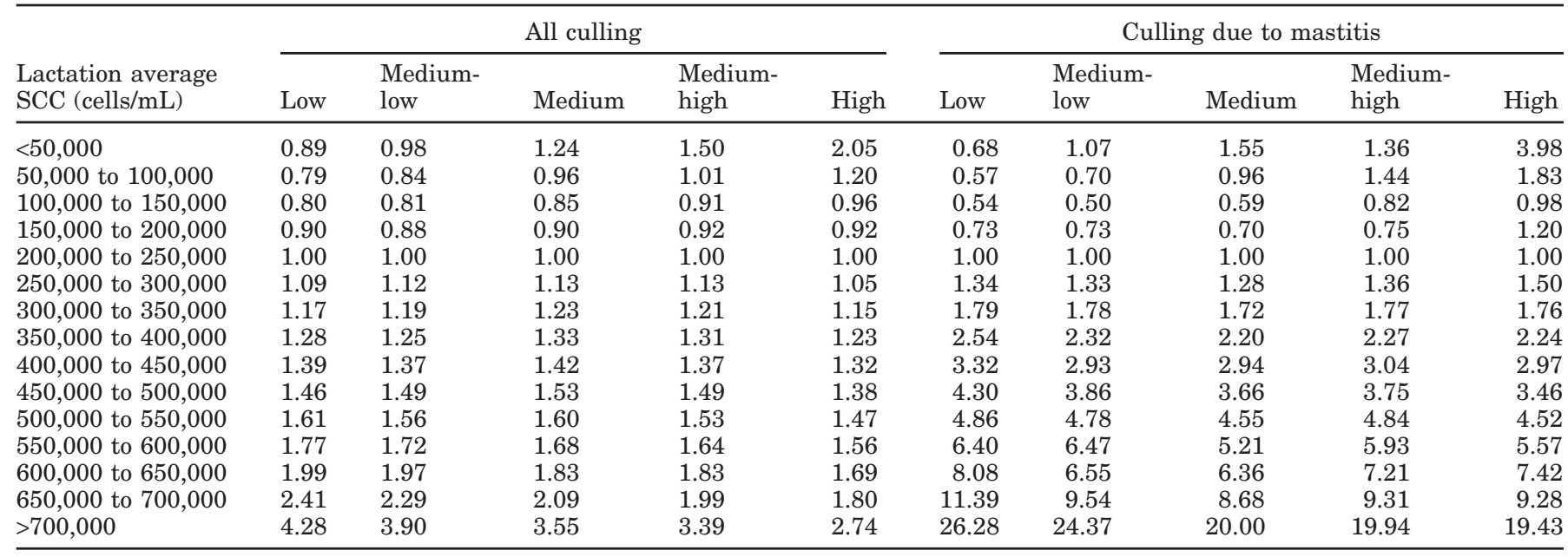

The relative risk of overall culling and culling due to mastitis for Jersey cows with varying lactation average SCC in low $(139,000$ to 306,000 cells $/ \mathrm{mL})$, medium $(306,000$ to 349,000 cells $/ \mathrm{mL})$, or high $(349,000$ to 491,000 cells $/ \mathrm{mL}$ ) SCC Jersey herds is shown in Table 3. Relative to Jersey cows with a lactation average SCC of 200,000 to 250,000 cells $/ \mathrm{mL}$, Jersey cows with high lactation average SCC had a much greater risk for culling, particularly in herds with low average SCC. For example, Jersey cows with lactation average SCC $>700,000$ cells $/ \mathrm{mL}$ had $\mathrm{RR}$ of 4.7 in herds with low SCC (compared with Jersey cows with SCC of 200,000 to 250,000 cells $/ \mathrm{mL}$ ) and RR of 2.7 in herds with high SCC. As in Holsteins, the risk of culling for Jersey cows with lactation average SCC of 600,000 to 650,000 cells $/ \mathrm{mL}$, as compared with average cows, ranged from 1.9 in low SCC herds to 1.6 in high SCC herds. This seems to indicate more stringent culling of cows with clinical or subclinical mastitis in herds that (apart from this cow) tend to have few mastitis problems. However, a similar pattern could be observed if a constant percentage of cows were culled due to CM or high SCC in all categories. For example, the poorest $10 \%$ of cows for SCC in a herd with excellent udder health would have lower average SCC than the poorest $10 \%$ of cows in herd with a significant mastitis problem, and culling the same proportion from each herd would necessitate more stringent culling for mastitis in the former (based on mean SCC of cows that were removed). As in Holsteins, individual Jersey cows that had extremely low lactation

Table 3. Relative risk of overall culling and culling due to mastitis for Jersey cows with differing lactation average somatic cell count (SCC) in low ( 139,000 to 306,000 cells $/ \mathrm{mL})$, medium (306,000 to 349,000 cells/ $\mathrm{mL})$, or high (349,000 to 491,000 cells/mL) SCC herds.

\begin{tabular}{|c|c|c|c|c|c|c|}
\hline \multirow{2}{*}{$\begin{array}{l}\text { Lactation average } \\
\text { SCC (cells } / \mathrm{mL} \text { ) }\end{array}$} & \multicolumn{3}{|c|}{ All culling } & \multicolumn{3}{|c|}{ Culling due to mastitis } \\
\hline & Low & Medium & High & Low & Medium & High \\
\hline$<50,000$ & 1.12 & 1.80 & 3.17 & 1.97 & 2.07 & 7.91 \\
\hline 50,000 to 100,000 & 0.92 & 1.07 & 1.35 & 0.94 & 1.54 & 2.44 \\
\hline 100,000 to 150,000 & 0.90 & 1.00 & 1.20 & 0.74 & 1.12 & 1.64 \\
\hline 150,000 to 200,000 & 0.91 & 0.94 & 1.05 & 0.80 & 0.81 & 0.97 \\
\hline 200,000 to 250,000 & 1.00 & 1.00 & 1.00 & 1.00 & 1.00 & 1.00 \\
\hline 250,000 to 300,000 & 1.07 & 1.07 & 1.13 & 1.19 & 1.20 & 1.14 \\
\hline 300,000 to 350,000 & 1.14 & 1.18 & 1.19 & 1.54 & 1.60 & 1.37 \\
\hline 350,000 to 400,000 & 1.17 & 1.19 & 1.23 & 1.86 & 1.79 & 1.57 \\
\hline 400,000 to 450,000 & 1.27 & 1.32 & 1.24 & 2.47 & 2.28 & 1.83 \\
\hline 450,000 to 500,000 & 1.34 & 1.38 & 1.36 & 3.12 & 2.58 & 2.22 \\
\hline 500,000 to 550,000 & 1.55 & 1.44 & 1.39 & 3.96 & 3.12 & 2.64 \\
\hline 550,000 to 600,000 & 1.82 & 1.49 & 1.42 & 5.80 & 3.91 & 2.98 \\
\hline 600,000 to 650,000 & 1.94 & 1.85 & 1.62 & 6.90 & 5.80 & 3.78 \\
\hline 650,000 to 700,000 & 2.35 & 2.04 & 1.81 & 9.28 & 8.13 & 4.80 \\
\hline$>700,000$ & 4.74 & 3.40 & 2.70 & 23.14 & 17.99 & 8.78 \\
\hline
\end{tabular}


average SCC (e.g., $<50,000$ cells $/ \mathrm{mL}$ ) appeared to be at greater risk for culling than cows in the reference class (with SCC of 200,000 to 250,000 cells $/ \mathrm{mL}$ ).

When failure was restricted to culling due to mastitis, Jersey cows with lactation average SCC of $>700,000$ cells/mL were 23.1 times more likely to be culled (for mastitis) than average cows in low SCC herds and 8.8 times more likely to be culled in high SCC herds. Similarly, Jersey cows with SCC of 600,000 to 650,000 cells/ $\mathrm{mL}$ had 6.9 times higher risk of culling in low SCC herds, and 3.8 times higher risk of culling in high SCC herds. Overall, it appeared that the culling criteria in high SCC herds might be stricter in Holstein herds than in Jersey herds.

Previous authors (e.g., Coffey et al., 1986; Shukken et al., 1994) have expressed concern that continuously decreasing SCC through genetic selection could lead to cows with impaired ability to recruit leukocytes and adequately respond to an IMI. Our results in Holsteins and Jerseys appear to indicate that cows with extremely low SCC may suffer from a reduced capacity to resist mastitis, particularly in herds with poor environmental conditions or poor udder health management practices (and, hence, high likelihood of exposure to mastitis pathogens). However, it is important to note (as shown in Figures 1 and 2) that the number of cows in the lowest SCC category was limited, particularly in herds with high average SCC. The results of Rupp and Boichard (2000), who compared SCC in the first month of first lactation with the subsequent time to CM infection, contradicted the results of the present study. In French Holsteins, the probability of CM increased continuously as the initial SCC level increased, and this pattern occurred in both low SCC and high SCC herds. These authors concluded that low initial SCC values are desirable, and that no "intermediate optimum" exists, with respect to SCC.

\section{CONCLUSIONS}

Survival analysis using Weibull proportional hazards models can be a powerful methodology for measuring the impact of SCC on the longevity of dairy cattle, due to the ability of these models to accommodate timedependent explanatory variables. The percentage of censored records, as well as the average age at culling or censoring, increased as herd average SCC decreased, indicating that cows tend to survive longer in herds with few mastitis problems. The relative risk ratios for Holstein and Jersey cows with high lactation average SCC (e.g., >700,000), as compared with "average" cows (with SCC of 200,000 to 250,000 cells $/ \mathrm{mL}$ ), were 2 to 4 times greater for overall culling and 10 to 25 times greater for culling due to mastitis. In both breeds, the relative risk of culling for high SCC cows tended to be greater in low SCC herds, perhaps indicating that these herds cull more stringently for CM and high SCC than other herds. Interestingly, cows with lactation average SCC less than 50,000 cells $/ \mathrm{mL}$ tended to have a slightly higher risk of culling than average cows, particularly in herds where mastitis pathogens are likely to be abundant. The optimal level of lactation average SCC, with respect to overall culling or culling due to mastitis, appeared to be approximately 100,000 to 150,000 cells/ $\mathrm{mL}$ in Holsteins and 150,000 to 200,000 cells $/ \mathrm{mL}$ in Jerseys in the present study. This phenomenon should be examined in more detail in future studies before any firm conclusions are drawn regarding the immunological capacity of low SCC cows. In addition, future studies should consider using test-day SCC values, rather than lactation average SCC (as in this study), because such data could give a more precise evaluation of the current udder health status of individual cows.

\section{ACKNOWLEDGMENTS}

Financial support of the National Association of Animal Breeders (Columbia, MO), the Holstein Association USA (Brattleboro, VT), the American Jersey Cattle Association (Reynoldsburg, $\mathrm{OH}$ ), and the Babcock Institute for International Dairy Research and Development (Madison, WI) is gratefully acknowledged. Vincent Ducrocq provided technical assistance, and the USDAARS Animal Improvement Programs Laboratory (Beltsville, MD) provided data.

\section{REFERENCES}

Barbano, D. M., R. R. Rasmussen, and J. M. Lynch. 1991. Influence of milk SCC and milk age on cheese yield. J. Dairy Sci. 74:369-388.

Coffey, E. M., W. E. Vinson, and R. E. Pearson. 1986. Potential of somatic cell concentration in milk as a sire selection criterion to reduce mastitis in dairy cattle. J. Dairy Sci. 69:2163-2172.

Cranford, J. L., and R. E. Pearson. 2001. Relationship of sire predicted transmitting ability for somatic cell score with measures of daughter performance. J. Dairy Sci. 84:1501-1507.

Ducrocq, V., and J. Sölkner. 1998a. Implementation of a routine breeding value evaluation for longevity of dairy cows using survival analysis techniques. Proc. 6th World Congr. Genet. Appl. Livest. Prod., Armidale, Australia, 23:359-362.

Ducrocq, V., and J. Sölkner. 1998b. The Survival Kit - V3.0; A package for large analyses of survival data. Proc. 6th World Congr. Genet. Appl. Livest. Prod., Armidale, Australia, 22:51-52.

Egger-Danner, C. 1993. Zuchtwertschätzung für merkmale der langlebigkeit beim rind mit methoden der lebensdaueranalyse. Ph.D. Diss., Univ. für Bodenkultur, Vienna, Austria.

Gröhn, Y. T., S. W. Eicker, V. Ducrocq, and J. A. Hertl. 1998. Effect of diseases on the culling of Holstein dairy cows in New York State. J. Dairy Sci. 81:966-978.

Neerhof, H. J., P. Madsen, V. P. Ducrocq, A. R. Vollema, J. Jensen, and I. R. Korsgaard. 2000. Relationships between mastitis and functional longevity in Danish Black and White dairy cattle using survival analysis. J. Dairy Sci. 83:1064-1071.

Rupp, R., and D. Boichard. 1999. Genetic parameters for clinical mastitis, somatic cell score, production, udder type traits, and 
milking ease in first lactation Holsteins. J. Dairy Sci. 82:21982204.

Rupp, R., and D. Boichard. 2000. Relationship of early first lactation somatic cell count with risk of subsequent first clinical mastitis. Livest. Prod. Sci. 62:169-180.

Shukken, V. H., B. A. Mallard, J. C. M. Dekkers, K. E. Leslie, and M. J. Stear. 1994. Genetic impact on the risk of intramammary infection following Staphylococcus aureus challenge. J. Dairy Sci. 77:639-647.

Vukasinovic, N. 1999. Application of survival analysis in breeding for longevity. Interbull Bull. 21:3-10.

Weller, J. I., A. Saran, and Y. Zeliger. 1992. Genetic and environmental relationships among somatic cell count, bacterial infection, and clinical mastitis. J. Dairy Sci. 75:2532-2540. 